\title{
夜間睡眠時の中途覚醒時間の長さと再入眠後の体温変動
}

$\begin{array}{ll}\text { 早稲田大学 } & \text { 佐々木由香122) } \\ \text { 東京都神経科学総合研究所 } & \text { 宮下 彰夫 } \\ & \text { 犬上 牧 } \\ \text { ノートルダム清心女子大学 } & \text { 石原 金由 } \\ \text { 福島大学 } & \text { 福田 一彦 } \\ \text { 日本学術振興会特別研究員 } & \text { 竹内 朋香 }\end{array}$

\section{Effects of the length of sleep interruption on body temperature after the subsequent sleep onset}

\author{
SASAKI, Yuka \\ Department of Psychology, Waseda University, Tokyo \\ MiYASITA, Akio \& INUGAMI, Maki \\ Department of Psychology, Tokyo Metropolitan Institure for Neuroscience, Tokyo \\ ISHIHARA, Kaneyoshi \\ Faculty of Home Economics, Notre Dame Seishin University, Okayama \\ FUKUDA, Kazuhiko \\ Department of Education Psychology, Fukushima University, Fukushima \\ TAKEUCHI, Tomoka \\ Research Fellow of the Japan Society for the Promotion of Science, Tokyo
}

This study investigated the effects of the length of sleep interruption on body temperature. Subjects were 5 male students mean aged 21.1 years old (19.5-22.1). We recorded polysomnography with measurement of rectal temperature (RT) during a whole night. Following two adaptation and one baseline nights, four consecutive nights were interrupted once a night at 20 min after the onset of NREM sleep in the 2nd sleep cycle. The length of sleep interruption was set at 10,40,60 and $90 \mathrm{~min}$. When sleep interruptions were of $10-\mathrm{min}$ and $40-$ min length, temporal patterns of RT were not different from the baseline night which was not interrupted. When the length of sleep interruption was 60 or $90 \mathrm{~min}$, drops of RT during the interval from the second lights-out to the point an hour after the second sleep onset were significantly larger in both conditions than in 10-min condition. In addition, the temporal position of minimum RT tended to be earlier as the interruption length was extended. The minimum RT appeared earliest when sleep interruption was $90 \mathrm{~min}$. There was no significant correlation between the drop of RT and the amount of SWS (slow wave sleep) during the period of $60 \mathrm{~min}$ after the 1st and 2nd sleep onset, suggesting that the drop of RT appears irrespective of the amount of SWS.

Key words: sleep interruption, body temperature, slow wave sleep

【要 約】健常な男子大学生 5 名を用い，夜間睡眠の中途覚醒時間の長さ $(10 \cdot 40 \cdot 60 \cdot 90$ 分)が再入眠後の直腸温に 与兄る影響を検討した。 その結果, 夜間睡眠時の中途覚醒時間が延長すると, 再入眠時に直晹温の低下が大きくなる といら結果を得た。この再入眠時の直腸温の低下は再消灯後から始まり, 中途覚醒時間が $60 \cdot 90$ 分条件での低下量は 初めの入眠時の直腸温低下量と差がなかった。 また, 一夜の直腸温変動について検討した結果, 中途覚醒時間が延長 すると，直腸温の最低温の出現する時間が早くなる傾向が認められた．再入眠時の直腸温低下量と SWS 出現量との 相関を検討したが，両者の間に相関は認められなかった。

1) Address correspondence and reprint requests to Yuka Sasaki, Department of Psychology, Tokyo Metropolitan Institute for Neuroscience, Musashidai 2-6, Fuchu-shi, Tokyo 183, Japan.

2) 現在の所属：郵政省通信総合研究所（科学技術特別研究員）

1994.4 .20 受稿, 1995.4 .12 受理 
ヒトの代表的な概日リズムに，体温リズムがあ る. 体温の変動は, 内因的のオシレータによる変 動と, 外因性の変動（マスキング）との両方があ る (Wever, 1985). 外因的変動要因として, 睡眠 (Mills, Minors \& Waterhouse, 1978), 食事, 行動 量, 姿勢(Samel, Wegmann \& Vejvoda, 1993)など が指摘されている。これらの外因的変動要因の中 で，睡眠はそれ自体が睡眠・覚醒リズムとして独 立したオシレータを持っていると考えられてお り，ヒトの代表的な概日リズムにとりあげられる ものである (Aschoff, 1965).

睡眠・覚醒リズムと体温リズムは，互いにまっ たく独立したリズムではなく，相互に影響しあう と考えられている。時差ボケやシフトワーカーの 心身不調なども，急激な睡眠期移行による体温リ ズムと睡眠・覚醒リズムとの間の内的脱同調の結 果であると考えられている (Klein, Wegmann \& Hunt, 1972; Tapp \& Natelson, 1989; Wegmann, Klein, Conrad \& Esser, 1983; Gundel \& Spencer, 1992)。また，早朝覚醒や徐波睡眠の減少などの睡 眠・覚醒リズムの変化を特徵とする嘼病にも, 体 温リズムの振幅変化が報告されている (Schulz \& Lund, 1983; Avery, Wildscødtz, Smallwood, Martin \& Rafaelsen, 1986). しかし，この睡眠・覚 醒リズムと体温リズムの交互作用については，い まだ充分に解明されてはいない.

睡眠・覚醒リズムと体温リズムの交互作用を検 討する手法は 2 つに大別できる．時間的手がかり の無い環境下に被験者を和いてフリーランさせる 方法と，実験者が睡眠期を統制したり中途覚醒さ せたりする方法である。いずれの方法による研究 も, 次に述べるように体温と睡眠との関連を示唆 している。

フリーランの実験からは, 体温リズムの下降相 や最低温期に入眠しやすいことが報告されている (Wever, 1979; Strogatz, Kronauer \& Czeisler, 1986)。また，体温リズムの下降相や最低温期に 入眠すると REM 睡眠が増加することが明らか
になった (Czeisler, Weitzman, Moore-Ede, Zimmerman \& Knauer, 1980).

実験者が睡眠期を統制する方法からは，同じ時 刻帯であっても覚醒時より睡眠時において, 体温 の振幅が大きく，かつ平均值が低くなり，さら に，入眠直後に最も大さな体温低下が生じること が報告されている(Barret, Lack \& Morris, 1993). また，この入眠期の体温低下は，一日の様々な概 日リズムの相に拈いても認められた (Gillberg \& Åkerstedt, 1982).

入眠期の体温低下は, 夜間睡眠を短時間中断し た後の再入眠期にも生じることを, Sasaki, Miyasita, Takeuchi, Inugami, Fukuda \& Ishihara (1993) が明らかにした。それによれば，夜間睡眠 の第 2 睡眠周期に括いて約 1 時間, 被験者を中途 覚醒させた結果, 再入眠時に基準夜よりも直腸温 が低下し,さらに, 最低温の出現時刻が基準夜よ り早くなった。

これに対して, Aschoff, Fatranska, Gerecke \& Giedke(1974)は, 夜間睡眠時に, 1 回20分の中 途覚醒を 1 夜に 2 度行ったが, 基準夜と比較し て, 最低温が出現する時期など, 全体的な直腸温 パタンに拈ける変化は認められなかったと結論し た。しかし，彼らは，中途覚醒後の再入眠時に一 過性に急激な体温の低下が生じたとも記述してい る.両報告の中途覚醒時間は異なっているため (1 時間と20分), 中途覚醒時間が体温変化に影 響するかどらかを検討する必要があろら．

睡眠中の体温変化は, 徐波睡眠 ( slow wave sleep; 以下 SWS )の量とも関連することが報告さ れている。それらは, 入眠時のSWS量は, 入眠時 の体温の絶対値や, 体温低下量と関連があると いうものである (Sewitch, Kittrell, Kupfer \& Reynolds, 1986; Horne \& Shackell, 1987; Sewitch, 1987; Berger, Palca, Walker \& Phillips, 1988; Bunnell, Agnew, Horvath, Jopson \& Wills, 1988; Jordan, Montgomery \& Trinder, 1990). 方, SWS の出現量と体温低下量の関連を否定す 
る報告もある (Dijk, Cajochen, Tobler \& Borbély, 1991; Sasaki et al., 1993). そこで, SWSが体温制 御にどの程度関わっているかを明らかにするた め, 体温の低下量と SWS 出現量との関連をさら に検討する必要があろう。

本研究では, 夜間睡眠の中途覚醒時間の長さを 変化させ, その後の再入眠に拈ける体温変化にど のように影響するか, また, 体温変化量とSWS出 現量に関連があるかどうかを検討した。

\section{方 法}

被験者 被験者は, 心身ともに健康な男子大学 生 9 名であった。 そのらち, 本研究での分析対象 としたのは，直腸温記録が完全に行われた 5 名で ある．この 5 名の平均年令は 21.1 歳（19.5-22.1 歳)であった.

手続き Fig. 1 に実験計画を示す．消灯は第 1 から 7 夜を通して，約 $23 ： 30$ とした。第 1 夜と第 2 夜の実験室順応夜, 第 3 夜の基準夜においては
中途覚醒を行わずに7.5時間の睡眠をとらせた． 第 4 夜から第 7 夜までの連続 4 夜を中途覚醒夜と し，第 2 睡眠周期が 20 分経過した時点で, 強制的 に被験者を覚醒させた。中途覚醒夜では, 中途覚 醒時間を除いた睡眠時間の合計が7.5時間に達し た時点で，被験者を起床させた。第 2 睡眠周期で 中途覚醒を行った理由は, 被験者の再入眠のしや すさに配慮したためと，第 1 睡眠周期に次いで SWS が出現し易い睡眠周期であるためである.

中途覚醒時間は， $10 \cdot 40 \cdot 60 \cdot 90$ 分とした。以 後，それぞれを W10・W40·W60・W90 条件とす る. 本実験は被験者内計画で行い，第 4 夜から， 1 夜に 1 条件ずっ, 連続 4 夜に割り振った. 条件 の順序系列については, 被験者間でカウンターバ ランスをとった。ただし，分析対象の 5 名に限る と,カウンターバランスは不完全であった.

中途覚醒時に扔いては，質問紙で被験者の自覚 症状（自覚症状調べ; 大島, 1979）や眠気（関学 式眠気調査 ; 石原・斎藤・宮田, 1982）について
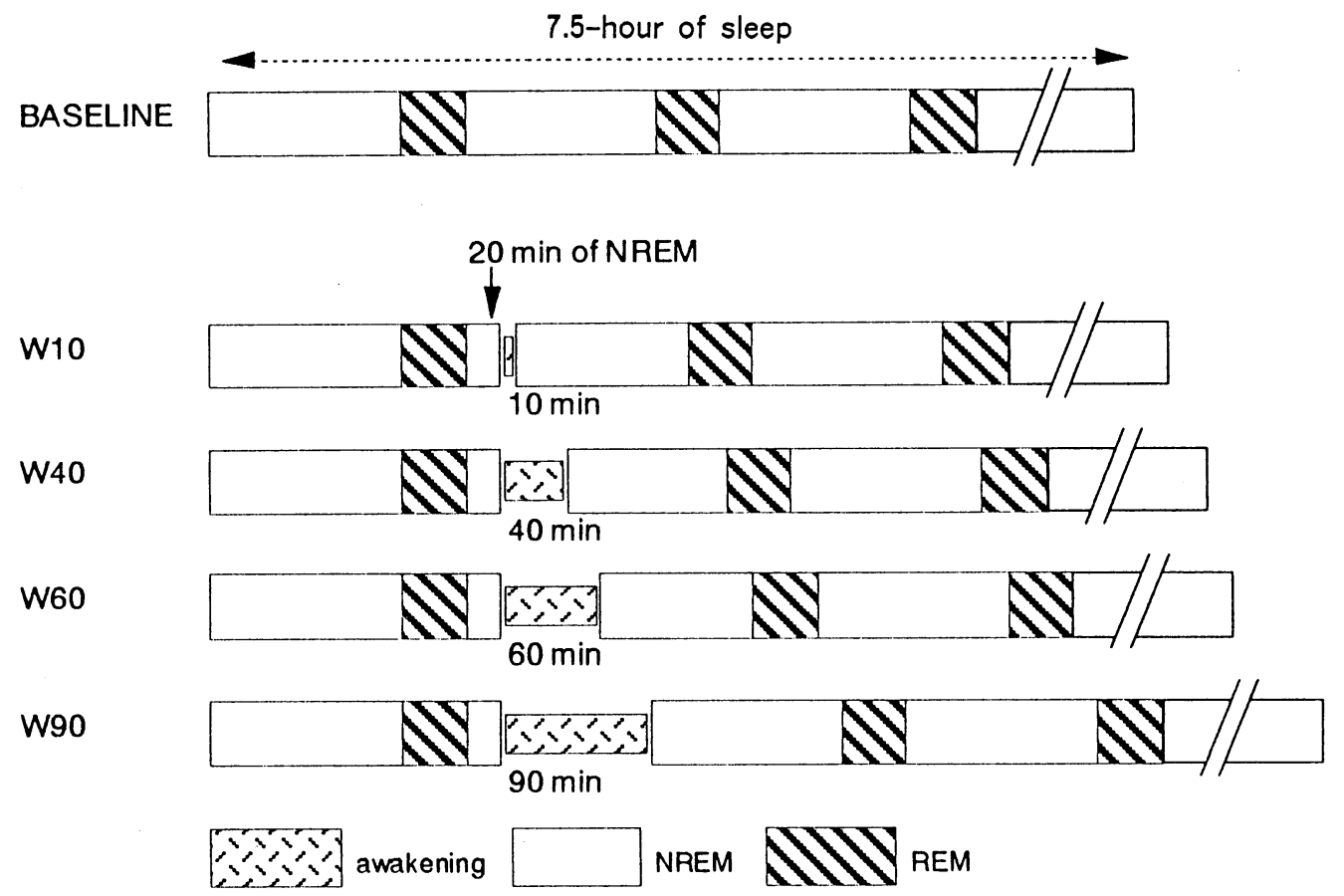

Fig. 1 Experimental design. 
調査した. W10 条件では, 質問紙記入の後, すぐ に再消灯した。それ以外の 3 条件では，睡眠実験 室内で椅子に座らせて, 聴覚性のヴィジランスタ スクを行った。このタスクを負荷する時間は， $\mathrm{W} 40$ 条件では20分間, W60 条件では40分間, W90条件では60分間とした。ただし，自覚症状や 眠気，扣よび，ヴィジランスタスクの結果につい ては, 本論ではふれない。

記録 睡眠時および中途覚醒時とも, 脳波, 眼 球運動, 筋電図, 直腸温, 心拍, 指尖容積脈波, 呼吸，皮膚電位活動を記録した。ただし，心拍， 指尖容積脈波, 呼吸, 皮膚電位活動の結果につい ては，本論では言及しない。脳波は10-20法に基 づき， $\mathrm{C}_{3}$ と $\mathrm{O}_{1}$ をあるいは $\mathrm{C}_{4}$ と $\mathrm{O}_{2}$ を，それぞ れ $\mathrm{A}_{2}$ あるいは $\mathrm{A}_{1}$ を基準として記録した。眼球運 動は, 左右の眼窩外側縁から， $\mathrm{A}_{2}$ あるいは $\mathrm{A}_{1}$ を 基準として水平方向運動を単極導出した．筋電は オトガイ筋より表面筋電図で記録した。脳波，眼 球運動, 筋電図は, ポリグラフ（三栄測器製 1A52sp 型) で紙送り $10 \mathrm{~mm} / \mathrm{s}$ にて記録した。睡眠 段階は, Rechtschaffen \& Kales(1968)の基準によ り30秒毎に視察判定した. 入眠は睡眠段階 1 の初 出の時点とした.ただし, 睡眠段階 1 の初出後, 段階Wにより睡眠が中断した場合，原則としてそ の後の睡眠段階 1 の再出現時点を入眠とした.

直腸温はサーミスタ温度計（芝浦電子製作所製 の MGAIII 型)を用いペン書き連続記録した。 サーミスタは，肛門より $15 \mathrm{~cm}$ から $20 \mathrm{~cm}$ 程挿入する よう被験者に教示した。直腸温はペン書き記録さ れたものを 30 秒ごとに読み取り，基準夜では入眠 後 1 時間ごとの平均值を算出した. 中途覚醒夜で は, 睡眠中 1 時間ごとの平均值に加えて, 中途覚 醒時間中の平均值と再消灯から再入眠をでの平均 値を算出した.

\section{結果}

中途覚醒時間 Table 1 亿, 各条件に扔㤝 途覚醒時間と再入眠潜時（再消灯から入眠まで）,
Table 1 Mean length and $S E$ of interruption and the 2nd sleep latency (min).

\begin{tabular}{lrcc} 
& interruption & 2nd sleep latency & total \\
\hline W10 & $8.7 \pm 0.49$ & $28.0 \pm 7.18$ & $36.7 \pm 7.36$ \\
W40 & $34.1 \pm 0.51$ & $14.3 \pm 1.27$ & $48.4 \pm 1.16$ \\
W60 & $54.8 \pm 0.16$ & $15.1 \pm 1.50$ & $69.9 \pm 1.41$ \\
W90 & $77.9 \pm 0.56$ & $20.8 \pm 2.50$ & $98.7 \pm 3.00$ \\
\hline
\end{tabular}

および，両者の合計時間の平均と標準誤差を示し た。 $\mathrm{W} 10$ 条件に括いて, 1 名の被験者の再入眠潜 時が99.5分と長かったため, 中途覚醒時間の平均 が設定条件である10分間を大幅に超えた４ 4 条 件間の中途覚醒時間 (中途覚醒時間と再入眠潜 時の合計) について, 繰り返しのある 1 要因の 分散分析を行ったところ, 条件間に有意差が認 められた $(F(3 / 12)=11.184, p<0.001)$. 下位検定 の結果, W10 条件と W90 条件 $(t=5.382, d f=12$, $p<0.05), \mathrm{W} 40$ 条件之 W90 条件 $(t=4.366, d f$ $=12, p<0.05)$ の間に有意差が認められた. 再入眠 潜時には条件差は認められなかった（繰り返しの ある一要因の分散分析： $F(3 / 12)=0.590, N S)$.

終夜の直腸温変動 Fig. 2 は, 基準夜と中途覚 醒夜の $\mathrm{W} 10 \cdot \mathrm{W} 40 \cdot \mathrm{W} 60 \cdot \mathrm{W} 90$ 条件それぞれの被験 者 5 人による平均直腸温と標準誤差を示してい る. 基準夜では, 入眠後420分に最低温を示した。 中途覚醒夜では，W10·W40 条件の直腸温が基準 夜と類似した变動を示した。これに対し， $\mathrm{W} 60 \cdot \mathrm{W} 90$ 条件では, 再消灯から再入眠までの間 に直腸温は大きく低下した。このよらに，中途覚 醒時間が延長すると, 再入眠時の直腸温の低下が 大さくなり, かつ, 直腸温が最低温を示す時期, すなわち, 直腸温が上昇し始める時期が早くなっ た。

初めの入眠時の直腸温(Fig. 2 の左端の 1 ポイン ト目）からの低下量を変量として，基準夜を含む 5 条件之時系列要因との 2 要因 $(5 \times 9)$ で, 繰 り返しのある分散分析を行った。中途覚醒夜で は, 中途覚醒期間中の值（図の）を除く 9 ポイ 
ントの 1 時間毎の值を用いた.

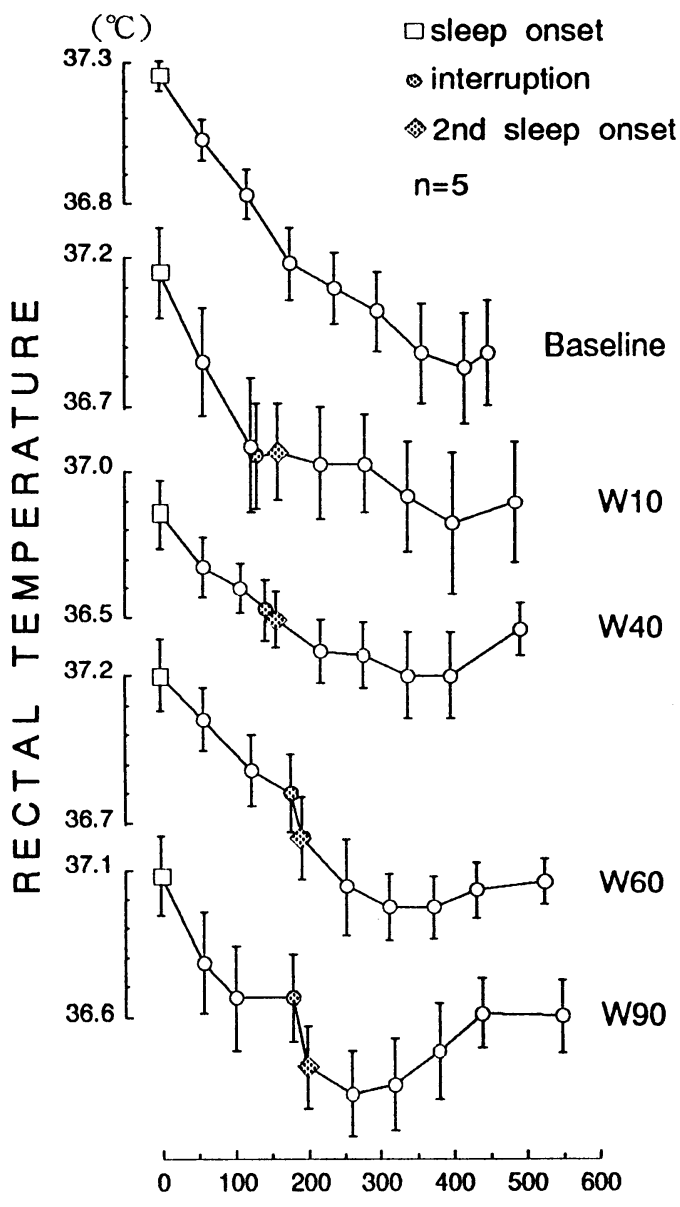

\section{Time From Sleep Onset (min)}

Fig. 2 Rectal temperature (RT) for baseline, W10, W40, W60 and W90 conditions. The first points at 0 min (sleep onset) represent mean RT from the 1st light-out to the 1st sleep onset. The closed circles stand for mean RT during the interruption. The closed diamonds show mean RT from the 2nd light-out to the 2nd sleep onset. The open circles are mean RT for one hour. These are proportionally plotted according to elapsed time from the 1st sleep onset. When the sleep before the interruption was longer than 2 hours, RT values obtained beyond 2 hours were included into the mean 2-hour point (the 2 nd open circles). So were the RT values beyond 5 hours following the interruption into the last points.
その結果，条件差による主効果は認められ なかったが $(F(4 / 16)=1.735, N S)$ ，時系列 $(F(8 / 32)=52.541, p<0.001)$, 招よび条件 $\times$ 時系列 の交互作用が有意であった $(F(32 / 128)=2.738$, $p<0.001)$.この交互作用について下位検定を行っ たところ， 7 ポイント目 $(F(4 / 144)=2.628$, $p<0.05), \quad 8$ ポイント目 $(F(4 / 144)=4.525, p<$ $0.005), 9$ ポイント目 $(F(4 / 144)=5.008, p<$ $0.001)$ に，中途覚醒条件間に有意差があった。ま た時系列要因は基準夜および全ての中途覚醒条件 に拈いて有意であった $(F(8 / 160) \geqq 7.288, p<$ 0.001). 以上の結果は, 中途覚醒時間の長さが, 再 入眠時の直腸温の低下量や, 直腸温の上昇し始め る時期に影響を与えたことを示唆している。

再入眠時の直腸温低下 中途覚醒を行った 4 条件の直腸温の低下量（絶対量）をはじめの入 眠後 1 時間と再入眠後 1 時間の間（入眠時期） で比較した (Table 2).2 要因の繰り返しのある 分散分析の結果, 条件間に有意差は認められな かったが $(F(3 / 12)=0.339, N S)$ ， 入眠時期の効果 $(F(1 / 4)=13.003, p<0.05)$ ，および条件 $\times$ 入眠時期 の交互作用が有意だった $(F(3 / 12)=4.022$, $p<0.05)$. この交互作用について下位検定を行っ た結果, W10 条件 $(F(1 / 16)=16.019, p<0.05)$ と $\mathrm{W} 90$ 条件 $(F(1 / 16)=9.200, p<0.05)$ で入眠時期の 効果が認められた。以上の結果は, 再入眠時の直 腸温低下量は，W40 およびW60条件では，はじめ の入眠期と同じ程度であるが, W10およびW90条 件では，はじめの入眠期の直腸温低下量より小さ

Table 2 Mean drop and $S D$ of rectal temperature for one hour after the 1st and 2nd sleep onset $\left({ }^{\circ} \mathrm{C}\right)$.

\begin{tabular}{llc} 
& 1st sleep onset & 2nd sleep onset \\
\hline W10 & $0.305 \pm 0.084$ & $0.033 \pm 0.152$ \\
W40 & $0.175 \pm 0.125$ & $0.113 \pm 0.067$ \\
W60 & $0.149 \pm 0.112$ & $0.170 \pm 0.094$ \\
W90 & $0.300 \pm 0.147$ & $0.094 \pm 0.037$ \\
\hline
\end{tabular}


いことを示している.

しかし，Fig. 2 に示した通り，W90 条件では $\mathrm{W} 10$ 条件と異なり再消灯から再入眠までにすで に直腸温が低下して扣り, 再入眠時の直腸温低下 量を吟味するためには，再消灯から再入眠までの 直腸温低下量を再入眠後の低下量と分けて検討す る必要がある. Fig. 3 は, 各中途覚醒条件での再 入眠時の直腸温低下を, 再消灯から再入眠直前ま での区間（図中の○）と再入眠後 1 時間の区間 （図中の○）とに分割し，両者の合計（図中の棒 グラフ）とともに示したものである。これらの直 腸温低下量は, 中途覚醒期間中の平均直腸温（縦 軸の 0 値）を基準にとり差を算出した.

再消灯から再入眠直前までの区間に括ける 直腸温は, W10 条件以外の条件で低下し, 中途 覚醒時間が延長すると, 直腸温の低下の度合が 大きくなった。さらに，再入眠後 1 時間の区間 の直腸温低下量も条件間で異なっている，そこ


Fig. 3 Rectal temperature changes around the 2nd sleep onset. Temperature changes $\left({ }^{\circ} \mathrm{C}\right)$ in the vertical axis represent difference from mean $\mathrm{RT}$ value during the interruption. The open circles represent mean RT changes from the 2nd light-out to the 2nd sleep onset. The closed circles indicate mean RT changes during one hour after the 2 nd sleep onset. The open bars show sum of both open and closed circles.
で直腸温の低下量について, 中途覚醒条件 $\times$ 区 間の 2 要因とも繰り返しのある分散分析を 行った。 その結果, 中途覚醒条件の主効果のみ が有意だった $(F(3 / 12)=6.486, p<0.01)$. 区間の 主効果 $(F(1 / 4)=0.038, N S)$, および 2 要因間の交 互作用 $(F(3 / 12)=1.478, N S)$ は認められなかった. 中途覚醒条件について下位検定を行ったところ $\mathrm{W} 10$ 条件と W60 条件との間 $(t=3.647, d f=12$, $p<0.05)$, 抢よび W10 条件と W90 条件との間 $(t=3.758, d f=12, p<0.05)$ に有意差が認められ た。これらは, 中途覚醒時間が延長すると, 再消 灯から再入眠後 1 時間経過した時点までの直腸温 低下量が大きくなることを示している。

また，Table 2 に拈いてW90条件で再入眠後 1 時間の直腸温低下量がはじめの入眠後 1 時間の直 腸温低下量より少なかったのはFig. 3 に示すとお り，W90条件で再入眠直前までに直腸温が大きく 低下していたためであると考光られる（図中の ○). 合計の低下量（図中の棒グラフ）では，4条 件のらち最大の低下量を示している.

最低温の出現時期 Fig. 2 に示した通り, 中途 覚醒時間が長いと, 直腸温の最低温の出現が早く なる、入眠から最低温出現までの平均経過時間と 標準偏差は，基準夜414.5 530.0 分, W10 条件 $376.8 \pm 104.4$ 分, W40 条件425.2 448.4 分, W60 条件347.9土96.5分, W90 条件285.6土21.7分で あった. 最低温の出現時期は 1 時間ごとに平均し た值から求めたため, 個々のデータには 1 時間の 幅があり，パラメトリックな検定になじをない。 そこで, 被験者内で, 5 夜に拈ける最低温の出現 時間について順位をつけフリードマン検定を行っ た. その結果, 有意ではないが差のある傾向が条 件間に認められた $\left(\chi^{2}=8.32, d f=4, p<0.1\right)$.

SWS 量と直腸温低下 基準夜. W10 $\mathrm{W} 40$. $\mathrm{W} 60 \cdot \mathrm{W} 90$ 条件に打ける終夜の平均 SWS 出現量と 標準偏差は，それぞれ，96.1土25.1分，94.4士 19.8 分, 99.5土14.8分, $94.0 \pm 19.3$ 分, $112.3 \pm$ 17.2分であった. 繰り返しのある 1 要因の分散分 
析の結果, 有意差は認められなかった $(F(4 / 16)=$ $1.170, N S)$. 再入眠後 1 時間に拈ける平均 SWS 出 現量と標準偏差は, $\mathrm{W} 10 \cdot \mathrm{W} 40 \cdot \mathrm{W} 60 \cdot \mathrm{W} 90$ 条件の 順に9.9土8.4分, $21.3 \pm 5.1$ 分, $22.4 \pm 9.4$ 分, $17.7 \pm 10.0$ 分となり, 繰り返しのある 1 要因の分 散分析を行ったが， 4 条件間に有意差は認められ なかった $(F(3 / 12)=1.827, N S)$. ちなみに, 全中途 覚醒夜の再入眠後 1 時間の平均 SWS 出現量は, 基準夜の第 2 睡眠周期に抢ける SWS 出現量 22.9 分の $77.8 \%$ に相当した。

次に, 再入眠後 1 時間に拈ける直腸温の変化量 とSWS の出現量について条件差を無視して両者 の相関を調べた. Fig. 4 に示すよらに, 再入眠後 1 時間に抢ける直腸温変化量と SWS 出現量の相 関は認められなかった。 $(r=-0.07, d f=18, N S)$. また，はじめの入眠期である第 1 睡眠周期におい ても両者の相関は認められなかった $(r=0.14, d f$ $=18, N S)$.



Fig. 4 Scattergram for the amount of SWS and rectal temperature changes for an hour following the 2 nd sleep onset.

\section{考察}

中途覚醒時間の長さと直腸温低下 再消灯から 再入眠までの直腸温変化量と再入眠後 1 時間の直 腸温低下量を合わせても W10 条件では直腸温の 低下はわずかであり，W60条件及びW90条件との 間に有意な差が認められた(Fig. 3). 再消灯から再 入眠までに, W10条件のみ平均直腸温はわずかに
上昇したが，これはW10条件で再入眠潜時が90分 を超えてしまった例外的被験者 1 名のみに起因す るのではない，それ以外にも 2 名, 計 3 名の被験 者の直腸温が中途覚醒時よりも上昇していた。今 回の結果は, 再入眠時にはじめの入眠期同様の直 腸温低下が起きることを示唆した Sasaki et al. (1993) の報告を基本的に支持している.

本研究は中途覚醒後の再入眠時に扝ける直腸温 低下が生じるか否かは，60分以上の覚醒時間の長 さが重要な要因であることを示している．Sasaki et al.(1993)は，夜間睡眠に拈ける中途覚醒時間を 約 1 時間とする条件下で, 再入眠時の直腸温低下 を検出し最低温の出現が前進することを示唆し た。今回の結果, 中途覚醒時間が長くなると直腸 温の最低温が早く出現する傾向が認められた (Fig. 2). Aschoff et al. (1974) は主として最低温 出現の時期に注目して分析を行ったが, 中途覚醒 時間が20分であったため, 最低温の出現時期が基 準夜と変わらなかったと考兄られる。このことか ら，夜間睡眠に括ける中途覚醒時間の長さについ て, 体温の变動に影響を与える閾値の存在が仮定 できよう。

健康成人でも夜間睡眠には数分間の自発的覚醒 が含まれている。（堀・渡辺，1967; Brezinová, 1975)。しかしながら体温は夜間睡眠中に大きな 変動を伴わず低下する (Geschickter, Andrews \& Bullard, 1966; Heller \& Glotzbach, 1977).つま り, 夜間睡眠中に生じるごく短時間の中途覚醒 は, 終夜の体温変動に影響しない, 短時間の中途 覚醒であれば，それを睡眠継続のための許容範囲 として処理すると考光られる。

これに対し，1時間を超える中途覚醒は, 今回 の結果から次のように推測できる. 長時間の覚醒 は睡眠継続の許容範囲から逸脱し, 再入眠する際 にはそれ以前の睡眠がリセット (Miyasita, Fukuda \& Inugami, 1989)され, 併せて入眠期の生理的作 用の一部 (Sasaki et al., 1993) としての直腸温低下 が再び生じるのであろう，逆に言えば再入眠時の 
直腸温の低下勾配や最低温の出現時期の前進は, 再入眠前の睡眠がリセットされたか否かを示す指 標としての可能性があるといえよう.

以上, 再入眠時の直腸温低下が睡眠りセット時 に特有の現象であることを示したが，ここでは， さらに別の $2 つ の$ 要因の影響についても検討を加 えたい。それらは，各条件での再入眠時における 体温の概日リズム上の位相差, および, 再消灯時 に生じる被験者の姿勢変化である. 以下に再入眠 時に認められた直腸温低下がこれら2つの要因で は説明できないことを示す。

まず，体温リズムの位相差についてであるが， 中途覚醒時間が長くなると, 各条件間で再入眠時 の概日リズムの位相が異なり，体温のセットポイ ント（堀・中山，1981）が異なっている可能性が ある。体温のセットポイントは体温が調節される べき目標值を意味するので, 朝方が最低となる概 日リズムを持つ. 中途覚醒のない基準夜がセット ポイントを反映した直腸温変動をしていると仮定 すれば，入眠から約420分までは，時間が経過す るほどセットポイントが低下していく(Fig. 2).し たがって, 中途覚醒時間の間に体温低下が生じな ければ，再入眠の時刻（入眠からの経過時間）が 遅いほど，その時の直腸温とセットポイントとの 差が大きくなり, 再入眠による体温低下勾配は大 きくなるとも予想できる.

この点から今回の結果をみると, 最初の入眠か ら中途覚醒後の再入眠までの平均経過時間は, $\mathrm{W} 10$ 条件では160分, W40 条件160分, W60 条件 190分, W90 条件200分であった W90条件では，およそ40分間の差しかなく，概日 リズムの位相差は無視できよう．また，中途覚醒 夜の再入眠時の直腸温と基準夜のほぼ同時刻の直 腸温の絶対値にも差が無かった $(F(4 / 16)=0.648$, $N S)$. したがって, 再入眠時のセットポイントの
条件差はないといえる。

また, Sasaki, Miyasita, Takeuchi, Inugami \& Fukuda (1991) は, 明らかに位相差のある第 2 睡眠周期と第 4 睡眠周期で60分間の中途覚醒を行 い, 再入眠時の直腸温の低下を比較した。しか し, 再消灯から再入眠後 1 時間にかけての直腸温 の低下量には両者に差がみられなかったことを示 唆している。つまり, 再入眠時に生じる直腸温低 下量は，仮に体温の概日リズム位相によってセッ トポイントが異なっていたとしても，その影響を 受けないと考えられる。

次に, 再入眠直前の直腸温低下に対する姿勢変 化の影響を検討する．Kleitman \& Doktorsky (1933) は, 日中に約 1 時間の立位後に続く仰臥位 開始時と終了時の直腸温を比較し, 覚醒時の仰臥 位では, 平均 $-0.02^{\circ} \mathrm{C}$ 直腸温が変化したことを報 告している.また, 同じ覚醒時の仰臥位でも, 引 き続き入眠してしまう場合は, 仰卧位開始時と終 了時 (入眠直前) との差が増加し, 平均 $-0.11^{\circ} \mathrm{C}$ の 変化であった。この仰臥位に続く睡眠開始と終了 時（平均睡眠持続時間52分）との差は平均 -0.15 ○であった.

今回得られた, 再消灯から再入眠までの直腸温 平均変化は, $\mathrm{W} 10$ 条件で+ $0.01{ }^{\circ} \mathrm{C}, \mathrm{W} 40$ 条件 $-0.03^{\circ} \mathrm{C}, \mathrm{W} 60$ 条件 $-0.14^{\circ} \mathrm{C}, \mathrm{W} 90$ 条件 $-0.23^{\circ} \mathrm{C}$ で あった(Fig. 3). Kleitman \& Doktorsky(1933)の直 腸温変化の算出方法は, われわれと若干異なる が，あえて比較すると，W10・W40 条件での直腸 温変化量は, 彼らの覚醒仰臥位期に括ける变化に 近く, $\mathrm{W} 60 \cdot \mathrm{W} 90$ 条件での直腸温変化量は, 入眠 直前に括ける仰臥位期の数值と等しいかあるいは それより大さい。よって，中途覚醒時間が 1 時間 を超える場合には, 再入眠潜時に差がなくても (Table 2), 入眠の準備段階である再消灯の時点か ら, 単なる姿勢変化 (仰臥位) による体温低下ょ

3) 各条件間に拈ける中途覚醒時間の差と, 入眠から再入眠までの経過時間の差は, このように一致しなかった。そ れは, 中途覚醒を行らタイミングを時刻や入眠からの経過時間を基準とせず，睡眠周期を基準としていたため， 睡眠周期の長さにばらつきがあったことによる結果である. 
りも大きく直腸温が低下し始めるといえる。

体温低下とSWS出現量 再入眠後のSWS出現 量と体温の低下量については有意な相関を見いだ さなかった(Fig. 4). Dijk et al. (1991), Sasaki et al.(1993)も, 入眠時の体温の低下とSWS出現量に ついて関連を認めて扣らず，今回の結果は，それ らと一致する。

しかし，入眠時に抢ける体温の絶対值と入眠後 の SWS 量との関連や, 入眠後の体温の低下量と SWS 量とに関連があるとする報告も多い，それ らの報告に共通する手続きは, 強制的な冷・熱の 温度負荷である。例えば, Sewitch et al.(1986)は 低環境温26.7-28.3 ${ }^{\circ} \mathrm{C}$ で被験者を全裸で入眠させ た. Berger et al. (1988) は, 低環境温下 $\left(21^{\circ} \mathrm{C}\right.$ と $\left.29^{\circ} \mathrm{C}^{4)}\right)$ で被験者を全裸で入眠させた。また， Horne \& Shackell (1987), Bunnell et al. (1988), Jordan et al.(1990)は，いずれも，入眠前に $41^{\circ} \mathrm{C}$ か ら $43^{\circ} \mathrm{C}$ の温水浴をさせ，その後の睡眠期に括ける SWS 量を測定するものであった。

Sewitch (1987) は,このよらな温度ストレス下 では睡眠の質が低下する可能性があると指摘して いる．寒冷ストレスを与える方法では，Sewitch et al. (1986) での睡眠効率が88.5\%に低下してい る. Berger et al.(1988)が典型例として報告した被 験者 1 名のデータは, 実験夜10夜中 SWS 量が80 分を超えたのは 1 夜のみで, 6 夜が50分前後, 3 夜が40分未満であった. 本研究の平均 SWS 出現 量は99.3分であり，これと比較すると彼らの SWS 出現量は半減していると考穴られる。また， 加温手続きを用いた Bunnell et al. (1988) も SWS 出現量の増加を認めず, Jordan et al. (1990) でも代謝量測定用のフェイスマスクにより 睡眠が障害され, SWS 量が統制条件で57分しか なかった。
一方, 入眠期に体温低下と SWS 出現量の関連 を認めていない報告は, 強制的な体温上昇や体温 低下の方法をとっていない. Dijk et al.(1991)は被 験者を00時から15時まで可能な限り睡眠をとら せ, その間の直腸温低下時期とSWS出現時期, お。 よび直腸温低下量と SWS 出現量が，それぞれ関 連していなかったことを報告している. Sasaki et al. (1993) は夜間睡眠に抢ける中途覚醒後の再入眠 時に, SWS の増加を伴わずに直腸温が低下した ことを報告している，本研究の結果も，はじめの 入眠時についても中途覚醒後の再入眠時について も，直腸温低下量と SWS 出現量との間に相関を 認めなかった。

以上, 入眠期の体温低下と SWS 量の関連が認 められるのは，被験者に対して強制的な温度スト レスを与えた結果, 睡眠効率や SWS 出現量が減 少している場合に限定されることを示した．被験 者に温度ストレスを与えない状況では，SWS 出 現量に関係なく入眠時に护ける体温低下が生起す ると考えられる。

\section{引用文献}

Aschoff, J. 1965 Circadian rhythms in man. Science, 148, 1427.

Aschoff, J., Fatranska, M., Gerecke, U. and Giedke, H. 1974 Twenty-four-hour rhythms of rectal temperature in humans: Effects of sleep-interruptions and test-sessions. Pflüg. Arch., 346, 215-222.

Avery, H. D., Wildschiødtz, G., Smallwood, R. G., Martin, D. and Rafaelsen, O. J. 1986 REM latency and core temperature relationships in primary depression. Acta. Psychiatr. Scand., 74, 269-280.

4）環境温 $29^{\circ} \mathrm{C}$ を低温とすることについて. 梁瀬(1984)によると, 寝具によって身体の周囲に形成される寝床気候


し, 彼らの被験者は, 低環境温に慣れていて, 全裸で入眠可能な被験者に限定されていた。さらに, Sewitch

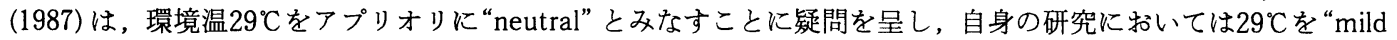
cold stress”と位置つけている. 
Barrett, J., Lack, L., and Morris, M. 1993 The sleep-evoked decrease of body temperature. Sleep, 16, 93-99.

Berger, R. J., Palca, J. W., Walker, J. M. and Phillips, N. H. 1988 Correlations between body temperature, metabolic rate and slow wave sleep in humans. Neurosci. Lett., 86, 230234.

Brezinová, V. 1975 The number and duration of the episodes of the various EEG stages of sleep in young and older people. Electroencephalogr. Clin. Neurophysiol., 39, 273-278.

Bunnell, D. E., Agnew. J. A., Horvath, S. M., Jopson, L. and Wills, M. 1988 Passive body heating and sleep: Influence of proximity to sleep. Sleep, 11, 210-219.

Czeisler, C. A., Weitzman, E. D., Moore-Ede, M. C., Zimmerman, J. C. and Knauer, R. S. 1980 Human sleep: Its duration and organization depend on its circadian phase. Science, 210, 1264-1267.

Dijk, D. J., Cajochen, C., Tobler, I. and Borbély. A. A. 1991 Sleep extention in humans: Sleep stages, EEG power spectra and body temperature. Sleep, 14, 294-306.

Geschickter. E. H., Andrews, P. A. and Bullard R. W. 1966 Nocturnal body temperature regulations in man: a rationale for sweating in sleep. J. Appl. Physiol., 21, 623-630.

Gillberg. M. and Åkerstedt, T. 1982 Body temperature and sleep at different times of day. Sleep, 5, 378-388.

Gundel, A. and Spencer, M. B. 1992 A mathematical model of the human circadian system and its application to jet lag. Chronobiol. Int., 9, 148-159.

Heller H. C. and Glotzbach S. F. 1977 Thermoreguration during sleep and hibernation.
International Review of Physiology Environmental physiology II, Volume 15 (Ed. David Robertshow) Baltimore: University Park Press.

堀忠雄・渡辺尊己 1967 ヒトの正常睡眠脳波の 推移. 臨床脳波, 11, 345-354.

堀哲郎 - 中山昭雄 1981 体温調節中枢 中山昭 雄 (編) 温熱生理学 理工学社 Pp. 253-280.

Horne J. A. and Shackell, B. S. 1987 Slow wave sleep elevations after body heating: Proximity to sleep and effects of Aspirin. Sleep, 10, 383-392.

石原金由・斎藤敬・宮田洋 1982 眠気の尺度と その実験的検討. 心理学研究, 52, 362-365.

Jordan. J., Montgomery, I. and Trinder, J. 1990 The effect of afternoon body heating on body temperature and slow wave sleep. Psychophysiology, 27, 560-566.

Klein, K. E., Wegmann, H. M. and Hunt, B. I. 1972 Desynchronization of body temperature and performance circadian rhythm as a result of outgoing and homegoing transmeridian flights. Aerospace Med., 43, 119-132.

Kleitman, N. and Doctorsky, A. 1933 The effect of the position of the body and of sleep on rectal temperature in man. Am. J. Physiol., 104, 340-343.

Mills, J. N., Minors, D. S. and Waterhouse, J. M. 1978 The effect of sleep upon human circadian rhythms. Chronobiologia, 5, 14-27.

Miyasita, A., Fukuda, K. and Inugami, M. 1989 Effects of sleep interruption on REM-NREM cycle in nocturnal human sleep. Electroencephalogr. Clin. Neurophysiol., 73, 107-116.

大島正光 1979 自覚的疲労状態 疲労の研究 第 2 版 同文書院 Pp. 123-144.

Rechtschaffen, A. and Kales, A. $1968 A$ manual of standardized terminology and 
scoring system for sleep stage of human subjects. Washington, D. C.: U.S. Government Printing Office.

Samel, A., Wegman, H-M. and Vejvoda, M. 1993 Response of the circadian system to $6^{\circ}$ head-down tilt bed rest. Aviat. Space Environ. Med., 64, 50-54.

Sasaki, Y., Miyasita, A., Takeuchi, T., Inugami, M. and Fukuda, K. 1991 The timing of nocturnal sleep interruption and pattern change of rectal temperature. Jpn. J. Psychiatr. Neurol., 45, 949. (Abstract)

Sasaki, Y., Miyasita, A., Takeuchi, T., Inugami, M., Fukuda, K. and Ishihara, K. 1993 Effects of sleep interruption on body temperature in human subjects. Sleep, 16, 478-483.

Sewitch, D. E., Kittrell, E. M. W., Kupfer, D. J. and Reynolds, C. F. 1986 Body temperature and sleep architecture in response to a mild cold dtress in women. Physiol. Behav., 36, 951-957.

Sewitch, D. E. 1987 Slow wave sleep deficiency insomnia: A problem in thermo-downregulation at sleep onset. Psychophysiology, 24, 200-215.

Schulz, H. and Lund. R. 1983 Sleep onset REM episodes are associated with circadian parameters of body temperature. A study in depressed patients and normal controls. Biol. Psychiat., 18, 1411-1426.

Strogatz, S. H., Kronauer, R. E. and Czeisler, C. A. 1986 Circadian regulation dominates homeostatic control of sleep length and prior wake length in humans. Sleep, 9, 353-364.

Tapp, W. N. and Natelson, B. H. 1989 Circadian rhythms and patterns of performance before and after simulated jet lag. Am. J. Physiol., 257, 796-803.
Wegmann, H. M., Klein, K. E., Conrad, B. and Esser P. 1983 A model for prediction of resynchronization after time-zone flights. Aviat. Space Environ. Med., 54, 524-527.

Wever, R. A. 1979 The circadian system of man. New York: Springer-Verlag.

Wever, R. A. 1985 Internal interactions within the human circadian system: the masking effect. Experientia, 41, 332-342.

梁瀬度子 1984 寝具 鳥居鎮夫（編） 睡眠の 科学 朝倉書店 Pp. 117-120. 